\title{
Immortalized Murine Striatal Neuronal Cell Lines Expressing Dopamine Receptors and Cholinergic Properties
}

\author{
Mark S. Wainwright, ${ }^{1}$ Bruce D. Perry, ${ }^{2, a}$ Lisa A. Won, ${ }^{1}$ Karen L. O'Malley, ${ }^{3}$ Wen-Yi Wang, ${ }^{1}$ Michelle E. Ehrlich, ${ }^{4}$ \\ and Alfred Heller ${ }^{\dagger}$ \\ 'Department of Pharmacological and Physiological Sciences and ${ }^{2}$ Department of Psychiatry, The University of Chicago, \\ Chicago, Illinois 60637, 3Department of Anatomy and Neurobiology, Washington University, St. Louis, Missouri 63110, and \\ ${ }^{4}$ Departments of Psychiatry and Cell Biology, New York University Medical Center, New York, New York 10016
}

Immortalized hybrid cells were generated by somatic cell fusion of 18-d-old embryonic corpus striatum of the mouse strain C57BL/6J with the N18TG2 neuroblastoma. One of the cell populations obtained was treated with a combination of $1 \mathrm{~mm} n$-butyric acid and $10 \mu \mathrm{m}$ SKF 38393 (a specific $D_{1}$ agonist), and a surviving cell population (E1X) was subcloned. Twenty-seven monoclonal cell lines were obtained and screened for the expression of striatal-specific characteristics including $\boldsymbol{\gamma}$-aminobutyric acid (GABA), choline acetyltransferase (ChAT), acetylcholine (ACh), mRNA for specific dopamine receptors, and dopamine- and adenosine $3^{\prime}: 5^{\prime}$-monophosphate-regulated phosphoprotein, $M_{r} \mathbf{3 2 , 0 0 0}$ (DARPP-32), and functional $D_{1}$ and $D_{2}$ dopamine receptors. Neither the parent hybrid cell population (E1X) nor any of the monoclonal cell lines examined expressed GABA levels significantly different than that of the N18TG2 parent neuroblastoma cells $(1.36 \pm 0.07 \mu \mathrm{g} / \mathrm{mg}$ protein). The range of ChAT activity in the monoclonal hybrid cell lines was $5.5 \pm$ 0.3 to $921.3 \pm 97.4 \mathrm{pmol} / \mathrm{min} / \mathrm{mg}$ protein. Two of the cell lines expressing ChAT activity (X52 and X58) contained ACh (49.64 \pm 4.23 and $1.78 \pm 0.07 \mathrm{ng} / \mathrm{mg}$ protein, respectively). The neuronal origin of four of the monoclonal hybrid lines was shown by their immunoreactivity, following differentiation with $10 \mu \mathrm{M}$ forskolin, to neurofilament protein, a neuronspecific marker. The monoclonal hybrid cell lines, but not the N18TG2 neuroblastoma, were shown to express an array of $D_{1}, D_{2}$, and $D_{5}$ receptor $m R N A$ as well as DARPP-32 $m R N A$. Two monoclonal cell lines expressed $D_{1}$ receptor binding sites (X57, $29.2 \pm 4.5 \mathrm{fmol} / \mathrm{mg}$ protein and X62, $43.8 \pm 6.8$ $\mathrm{fmol} / \mathrm{mg}$ protein) which mediated the stimulation of adenylate cyclase activity. One cell line, $\times 58$, expressed only $D_{2}$ dopamine receptors $(80.9 \pm 9.8 \mathrm{fmol} / \mathrm{mg}$ protein) which were

\footnotetext{
Received Jan. 21, 1994; revised June 27, 1994; accepted July 13, 1994.

This work was supported by NIMH Predoctoral award MH-10262 (M.S.W.), MH-28942 (A.H.), MH-45019 (K.O'M.), NS 5448S (K.O'M.), MH-00945, and MH-47028 (M.E.E.) and by funds provided by the Brain Research Foundation, an affiliate of The University of Chicago. We thank Domenico Vigilante, Nancy Bubula, Linda Sherman, Steve Harmon, and Steve Price for their expert technical assistance; Paul Kontur for his assistance with the initial fusion of the cells; and P.C. Hoffmann for a critical reading of the manuscript. Monoclonal antibodies $4.3 \mathrm{~F}_{9}$ and $2.2 \mathrm{~B}_{10}$ were kindly provided by $\mathrm{J}$. Q. Trojanowski, Department of Pathology, University of Pennsylvania School of Medicine, Philadelphia, PA.

Correspondence should be addressed to Alfred Heller, Department of Pharmacological and Physiological Sciences, The University of Chicago, 947 E. 58th Street, Chicago, IL 60637

a Present address: Department of Psychiatry, Baylor College of Medicine, Houston, TX 77030.

Copyright (c) 1995 Society for Neuroscience $0270-6474 / 95 / 150676-13 \$ 05.00 / 0$
}

negatively coupled to adenylate cyclase activity. These findings suggest that the immortalized monoclonal hybrid cell lines are of neuronal origin and have incorporated elements of the medium spiny and cholinergic neurons of the developing striatum.

IKey words: dopamine receptors, neuronal cell lines, $\mathrm{ACh}$, ChAT, corpus striatum, DARPP-32]

The basal ganglia play a central role in the integration of information from the limbic system and neocortex (for reviews see Bannon and Roth, 1983; Graybiel and Ragsdale, 1983; Graybiel, 1990; Gerfen, 1992). The involvement of the basal ganglia in sensorimotor function is evidenced by the clinical sequelae of neurodegenerative diseases including Parkinson's disease and Huntingtons's chorea (Hornykiewicz, 1973, 1979; Seeman et al., 1989). Dysfunction of mesocortical dopaminergic systems has also been implicated in neuropsychiatric disorders including schizophrenia (Seeman, 1987; Carlsson, 1988; Seeman et al., 1993). A number of neuronal compartments within the corpus striatum have been defined on the basis of their morphology, afferent projections, or neurochemical phenotype (Graybiel, 1990; Gerfen, 1992; Stoof et al., 1992). The regulation of the synthesis and release of neurotransmitters within each of these compartments is under complex control from several pathways including the nigrostriatal dopaminergic projection to the medium spiny neurons which comprise the majority of the neuronal population of the corpus striatum. The effects of dopamine within the corpus striatum are mediated by at least two dopamine receptor subtypes, $D_{1}$ and $D_{2}$. Dopamine receptors have been classified as $D_{1}$-like $\left(D_{1}, D_{5}\right)$ and $D_{2}$-like $\left(D_{2}, D_{3}, D_{4}\right)$ receptor families based on their molecular sequence and pharmacological properties (for review see Kebabian and Calne, 1979; Andersen et al., 1990; Grandy and Civelli, 1992; Sibley and Monsma, 1992; Gingrich and Caron, 1993).

The study of specific neuronal interactions is limited in vivo and in primary cultures of corpus striatum neurons by the heterogeneity of the primary corpus striatum cell population and the limited amounts of tissuc availablc. One approach to this issue has been to employ cell lines which are derived from, or express neurochemical properties of, the brain region of interest. Immortalized cell lines which provide unlimited amounts of tissue have been obtained by spontaneous transformation events or the introduction of transforming oncogenes (Cepko, 1989; Lendahl and Mckay, 1990). Spontaneous transformation has provided a number of widely studied cell lines including the PC12 cell line arising from a rat pheochromocytoma (Greene 
and Tischler, 1976). Spontaneous generation of a human neuronal cell line (Ronnett et al., 1990) has also been reported, but such transformations are a rare event. In contrast, retroviralmediated oncogene transduction may immortalize neuroblasts at a high rate of efficiency, but this approach has not successfully produced cells which express a specific neurotransmitter phenotype (Cepko, 1989; Lendahl and Mckay, 1990; Eves et al., 1992). Neuroblastoma and retinoblastoma cell lines which express dopamine receptors are available (Balmforth et al., 1986, 1988; Monsma et al., 1989; Sidhu and Fishman, 1990; Ivins et al., 1991; Lovenberg et al., 1991) in addition to the COS-1 line which is derived from renal epithelium (Steffey et al., 1991). However, while such cell lines are homogenous and provide an unlimited supply of tissue for biochemical analyses, they are not derived from the brain and therefore may be of somewhat limited utility in the study of neuronal cell-cell interactions in specific brain regions.

Somatic cell fusion is an alternative technique that permits the immortalization of postmitotic neuronal cells from brain regions which express specific neurotransmitter phenotypes (Hammond et al., 1986; Lee et al., 1990a,b; Choi et al., 1991; Crawford et al., 1992). Furthermore, cell lines produced in this manner may be used as models for the examination of the molecular mechanisms governing the differential expression of specific neurochemical phenotypes (Choi et al., 1992). Somatic cell fusion has been used for the generation of adrenergic cell lines from the peripheral nervous system (Greene et al., 1975) as well as those of central nervous system lineage including septal, hippocampal (Hammond et al., 1986, 1990; Lee et al., 1990a,b), and ventral spinal cord (Cashman, 1991) cell lines. In addition, this technique has been used to establish dopaminergic cell lines derived from embryonic murine mesencephalic neurons (Choi et al., 1991) as well as a rat mesencephalic cell line (Crawford et al., 1992). As an approach to developing model systems to provide a stable, homogenous model of primary corpus striatum neurons, we have used the somatic cell fusion technique to generate monoclonal cell lines of neuronal origin from the corpus striatum. The immortalized monoclonal corpus striatum hybrid cell lines described in this report express an array of dopamine receptor mRNA, as well as dopamineand adenosine $3^{\prime}: 5^{\prime}$-monophosphate-regulated phosphoprotein, $M_{r}$ 32,000 (DARPP-32) mRNA, functional $\mathrm{D}_{1}$ and $\mathrm{D}_{2}$ dopamine receptors, and choline acetyltransferase activity, and synthesize acetylcholine. The neurochemical profiles of the monoclonal hybrid cell lines indicate that the immortalized hybrid cell lines are derived from the fusion of N18TG2 cells with embryonic medium spiny and cholinergic neurons of the developing corpus striatum.

\section{Materials and Methods \\ Materials}

The embryonic mice used in these experiments were of the C57BL/6J strain. Pregnant mice were obtained from controlled matings in a closed colony derived from Jackson Laboratory stock. Mice were housed with a constant light-dark cycle of $12 \mathrm{hr}$ and fed a breeding diet of mouse chow containing $10 \%$ fat (Teklab).

All solutions used in tissue culture were filtered through $0.22 \mu \mathrm{m}$ sterile filters (Nalgene) and stored in sterile bottles at $4^{\circ} \mathrm{C}$. Dulbecco's modified Eagle medium (DMEM), fetal bovine serum (FBS), trypsin, and penicillin-streptomycin (5000 units penicillin; 5000 units streptomycin per $\mathrm{ml}$ ) were obtained from Grand Island Biological Company. DNase was obtained from Worthington Biochemical. Media for cell lines in monolayer culture consisted of DMEM plus $10 \%(\mathrm{v} / \mathrm{v})$ FBS and $1 \%(\mathrm{v} / \mathrm{v})$ penicillin-streptomycin unless stated otherwise. Forskolin,
$\mathrm{R}(+)$ SKF-38393, Quinpirole $\mathrm{HCl},(\mathrm{R}+)$ SCH-23390, and S(-) Eticlopride were obtained from Research Biochemicals International (Natick, MA).

\section{Dissection and somatic cell fusion}

Embryonic day $18 \mathrm{C} 57 \mathrm{BL} / 6 \mathrm{~J}$ mouse embryos were employed as the source of primary corpus striatum cells. $\mathrm{C} 57 \mathrm{BL} / 6 \mathrm{~J}$ cells express hypoxanthine phosphoribosyltransferase (HPRT) activity (Greene et al., 1975; Lee et al., 1990a,b). The neuroblastoma fusion partner was the N18TG2 cell line, which is deficient in HPRT and therefore unable to utilize exogenous sources of hypoxanthine for purine synthesis (Greene et al., 1975). Following fusion, the cells were cultured in a medium containing hypoxanthine, aminopterin, and thymidine (HAT medium). Since aminopterin blocks endogenous pathways required for purine and pyrimidine synthesis, the parent N18TG2 cells, which cannot utilize hypoxanthine, do not survive in this medium. Hybrid cells resulting from the fusion of N18TG2 and primary corpus striatum cells have the HPRT defect corrected by the inclusion of chromosomes from parental primary brain cells, thus enabling the hybrid cells to express HPRT and utilize exogenous sources of hypoxanthine. The neuroblastoma cell line was previously obtained through chemical mutagenesis of the N18 neuroblastoma, a subclone of the $\mathrm{C} 1300$ neuroblastoma isolated from an $\mathrm{A} / \mathrm{J}$ mouse (Minna et al., 1975). The N18TG2 cell line expresses negligible levels of choline acetyltransferase (ChAT) activity (Greene et al., 1975; Hammond et al., 1986, 1990; Blusztajn et al., 1992).

Embryos were removed from C57BL/6J mice killed by cervical dislocation on the 18th day of gestation and staged according to the criteria of Gruneberg (1943). The embryonic brain dissection procedure has previously been described in detail (Hemmendinger et al., 1981). The dissociation of primary corpus striatum cells and their fusion with N18TG2 cells was carried out as previously described for the generation of septal cholinergic and mesencephalic dopaminergic cell lines (Hammond et al., 1986; Choi et al., 1991), using a modification of the procedure described by Fournier (1981). Briefly, dissociated CS cells were suspended in $2.5 \mathrm{ml}$ of DMEM containing phytohemagglutinin-P (100 $\mu \mathrm{g} / \mathrm{ml}$ ) (Sigma, St. Louis). The cell suspension was then pipetted onto a $60 \mathrm{~mm}$ culture plate containing N18TG2 cells at approximately $70 \%$ confluence. After a $15 \mathrm{~min}$ incubation at $37^{\circ} \mathrm{C}$, the medium was aspirated and the cells were exposed to $50 \%(\mathrm{v} / \mathrm{v})$ polyethylene glycol (PEG 1000 , Koch-Light) for $1 \mathrm{~min}$ at room temperature. These procedures are described in detail in Wainer and Heller (1992). The fusion products were incubated overnight in culture medium (DMEM supplemented with $10 \%$ fetal bovine serum) and replated in HAT medium to select for the expression of hybrid cells. Control fusions included N18TG $2 \times$ N18TG2 and corpus striatum $\times$ corpus striatum cells. Neither of these fusions produced viable colonies. Therefore, any surviving colonies probably arose from hybrid cells derived from the fusion of corpus striatum cells with N18TG2 cells. One of the initial fusion products screened for specific ${ }^{125} I-S C H 23982$ binding to $D_{1}$ receptor binding sites was treated for $5 \mathrm{~d}$ with a combination of $1 \mathrm{~mm}$-butyric acid and a specific $D_{1}$ dopamine receptor agonist (SKF 38393). This treatment was selected in an attempt to increase the expression of $D_{1}$ receptors in light of the earlier demonstration of the differentiating effects of n-butyric acid on cultured cells (Prasad and Sinha, 1976) and on somatic cell hybrid cell lines (Choi et al., 1991). In addition, previous studies (Monsma et al., 1990b) have shown that elevation of cyclic adenosine monophosphate (cAMP) using a membrane-permeable cyclic AMP analog leads to an increase in the expression of functional dopamine receptors in a retinoblastoma cell line. The use of a specific $D_{1}$ agonist was, therefore, intended to promote the expression of $D_{1}$ receptors by stimulation of adenylate cyclase consistent with the report of Monsma et al. (1990b) as well as that of Zhou et al. (1992) of the presence of a cAMP response element in the $D_{1}$ receptor gene. While only $5 \%$ of the cells survived this treatment, it was possible to obtain a cell population (E1X) from the surviving colonies which does express $D_{1}$ and $D_{2}$ receptors. This cell population was then expanded and subcloned. Twenty-seven monoclonal cell lines were obtained and selected for further characterization.

\section{Freezing of cell cultures}

Cryostorage was performed as described previously for the freezing of mesencephalic hybrid cell lines (Choi et al., 1991). The freezing medium consisted of HEPES-buffered DMEM supplemented with 20\% FBS and $10 \%(\mathrm{v} / \mathrm{v})$ dimethyl sulfoxide (Fisher Scientific, Fair Lawn, NJ). 


\section{Radioligand binding studies}

Membrane preparation for dopamine receptor characterization. Cells were cultured on $100 \mathrm{~mm}$ Falcon plates. Media were aspirated and the monolayer cultures washed three times with harvesting buffer $[50 \mathrm{~mm}$ Tris- $\mathrm{HCl}$ buffer $\left(\mathrm{pH} \mathrm{7.7)}\right.$ at $5^{\circ} \mathrm{C}$ with $5 \mathrm{~mm}$ NaEDTA and $120 \mathrm{~mm}$ $\mathrm{NaCl}$. After washing, the cells were harvested by mechanical disruption with a rubber policeman. The tissue was flash frozen in liquid nitrogen and stored at $-70^{\circ} \mathrm{C}$. Immediately prior to assay, tissue was thawed slowly on ice, and disrupted by homogenization (Heidolph homogenizer, Polyscience Corp, Niles, IL) with 10 up strokes at low speed in 20 volumes of harvesting buffer. The homogenate was centrifuged at $43,000 \times g$ for 20 min at $4^{\circ} \mathrm{C}$ (Dupont, Sorvall RC28S with an SM24 head) and the resultant pellet suspended in $50 \mathrm{~mm}$ Tris $\mathrm{HCl}(\mathrm{pH} 7.4$ at $37^{\circ} \mathrm{C}$ ) with $120 \mathrm{~mm} \mathrm{NaCl}$.

Radioligand binding methods for $\mathrm{D}_{1}$ and $\mathrm{D}_{2}$ dopamine receptor binding sites were adapted from Sidhu and Kebabian (1985) as described previously (Farfel et al., 1992). D, binding sites were labeled with ${ }^{3} \mathbf{H}-$ SCH 23390 (NEN Dupont, $80 \mathrm{Ci} / \mathrm{mmol}$ ) or ${ }^{125} \mathrm{I}-\mathrm{SCH} 23982$ (NEN Dupont, $2200 \mathrm{Ci} / \mathrm{mmol}) . \mathrm{D}_{2}$ binding sites were labeled with ${ }^{3} \mathrm{H}$-spiperone (NEN Dupont, $32.4 \mathrm{Ci} / \mathrm{mmol}$ ). $\mathrm{D}_{1}$ receptor binding sites were quantified using saturation studies (six or eight concentrations ranging from $0.02-0.9 \mathrm{nM}$ ). Aliquots of tissue (final concentration $100-300 \mu \mathrm{g}$ protein $/ \mathrm{ml}$ ) were incubated with increasing concentrations of radioligand for $45 \mathrm{~min}$ at $37^{\circ} \mathrm{C}$ in a final volume of $240 \mu$ l. Specific binding was defined hy $100 \mu \mathrm{M}$ fluphenazine. Ketanserin $(10 \mu \mathrm{M})$ was included in all tubes to inhibit radioligand binding to $5-\mathrm{HT}_{2}$ serotonin receptor binding sites. For the $\mathrm{D}_{2}$ assays, increasing concentrations of ${ }^{3} \mathrm{H}$-spiperone (six concentrations ranging from 0.04-0.7 nM) were incubated with aliquots of tissue (final concentration $75-250 \mu \mathrm{g}$ protein $/ \mathrm{ml}$ ) for $45 \mathrm{~min}$ at $25^{\circ} \mathrm{C}$ in Tris- $\mathrm{HCl}$ buffer $\left(\mathrm{pH} 7.5\right.$ at $25^{\circ} \mathrm{C}$ ) with $120 \mathrm{mM} \mathrm{NaCl}$ and $0.01 \%$ bovine serum albumin. Final assay volume was $300 \mu \mathrm{l}$. Specific binding was defined by $10 \mu \mathrm{M}$ haloperidol. Ketanserin $(10 \mu \mathrm{M})$ was included in all tubes to inhibit radioligand binding to $5-\mathrm{HT}_{2}$ serotonin receptor binding sites.

For all assays, incubation was terminated by filtration under reduced pressure over Whatman GF/B filters (pretreated with $0.3 \%$ poly-L-lysine) using a Brandel Cell Harvester modified for radioligand binding assays. Filters were rinsed three times with $5.0 \mathrm{ml}$ ice-cold $50 \mathrm{~mm}$ TrisHCl buffer ( $\mathrm{pH} 7.7$ at $25^{\circ} \mathrm{C}$ ). The filters were dried overnight and placed in disposable glass minivials (Research Products International). Three milliliters of a $95 \%$ Econofuor $/ 5 \%$ Protosol solution (NEN, Waltham, MA) was added and the samples counted by liquid scintillation spectrophotometry (Beckman Model LS 5000TD) with an efficiency of $45 \%$.

Screening of fusion products for dopamine receptor binding sites. Twenty-five cell populations produced by the initial fusion of N18TG2 and primary corpus striatum cells were screened for ${ }^{125} \mathrm{I}-\mathrm{SCH} 23982$ specific binding. Cells were cultured on $100 \mathrm{~mm}$ Falcon plates. Harvesting of the cells and membrane preparations for the binding assay were essentially as described by Monsma et al. (1989). The concentration of radioligand used was 0.6 nM.

Subcloning of the fusion products. One of the cell populations derived from the initial fusion of E1 8 corpus striatum with N18TG 2 cells expressed high levels of ${ }^{125} \mathrm{I}-\mathrm{SC}$.H 23982 binding sites. This cell population was treated with a combination of $1 \mathrm{~mm} n$-butyric acid and a $D_{1}$ agonist (SKF 39893, $10 \mu \mathrm{M}$ ) for $5 \mathrm{~d}$. Less than 5\% of the cells survived this treatment. One surviving population (E1X) was selected, expanded, and subcloned for further characterization. Subcloning of single cells from this colony was carried out using a modification of the single-cell plating technique (Puck et al., 1956) as described previously (Choi et al., 1991). Twenty-seven monoclonal cell lines were produced and characterized as described below.

HPLC determination of endogenous $\gamma$-aminobutyric acid levels. Measurement of endogenous $\gamma$-aminobutyric acid (GABA) levels was performed as described previously (Kontur et al., 1987) using a modification of the method of Lasley et al. (1984). Briefly, cells were removed from the culture plates by mechanical disruption in $1 \mathrm{ml} \mathrm{of} 0.008 \mathrm{mg} /$ $\mathrm{ml} \alpha$-aminobutyric acid. The cell suspension was then sonicated and immediately stored at $4^{\circ} \mathrm{C}$. An aliquot of the supernatant was derivatized with $O$-phthaldialdehyde and the indole derivative was subsequently separated and quantified by high-performance liquid chromatographic analysis with electrochemical detection (HPLC-ED). The chromatographic system consisted of a Milton Roy minipump (model 396), a 5 $\mu \mathrm{m}$ octadecyl $4.6 \times 50 \mathrm{~mm}$ reverse-phase column (IBM), and an amperometric detector (BAS LC4) with a glassy carbon electrode (BAS
M-800). The mobile phase consisted of a sodium monobasic phosphate buffer $(0.1 \mathrm{M})$ containing EDTA $(0.134 \mathrm{M})$ and $35 \%(\mathrm{v} / \mathrm{v}) \mathrm{HPLC}$ grade methanol at a $\mathrm{pH}$ of 5.6. The carbon electrode was maintained at a potential of $+0.8 \mathrm{~V}$ versus the silver chloride reference electrode with a sensitivity of $20 \mathrm{nA} / \mathrm{V}$.

Choline acetyltransferase activity and endogenous acetylcholine content. Choline acetyltransferase (ChAT) activity was measured using a modification of the method of Fonnum (1975) (Hammond et al., 1986, 1990). ChAT specific activity was expressed as picomoles of acetylcholine formed per minute per milligram protein. Background signal was determined by assaying citrate-phosphate buffer instead of cell extract. Acetylcholine (ACh) levels were determined by HPLC-ED with an enzymatic reactor containing acetylcholinesterase and choline oxidase based on the method of Potter et al. (1983). The materials used were obtained from Bioanalytical Systems Inc. (West Lafayette, IN).

Identification of dopamine receptor and $D A R P P-32 \mathrm{mRNA}$ expression by polymerase chain reaction. Oligonucleotide primers were synthesized on an Applied Biosystems DNA synthesizer. Given the high degree of identity across species (for example, the mouse $D_{2}$ sequence shows $97 \%$ nucleic acid homology with the rat $\mathrm{D}_{2}$ sequence; Mack et al., 1991), dopamine receptor-specific oligonucleotides used for this study were primarily derived from rat receptor sequences unless the mouse sequence was known. All of the chosen probes generated the predicted size fragment which was further verified using internal oligonucleotides as hybridization probes. For the $\mathrm{D}_{1}$ receptor, sequences were derived from Monsma et al. (1990a) and included: $0654,5^{\prime}$-TCACTGCTCATCCTGTCCAC, identical to nucleotides 503-522; and 0643, 5'GAGCACATGATGTCAAAGGC, which is complementary to nucleotides 713-732. The $\mathrm{D}_{2}$ receptor primers o197, o198 were as described by O'Malley et al. (1990). The $\mathrm{D}_{3}$ receptor primers were derived from Sokoloff et al. (1990) and included: o580, 5'-TGGGCTATGGCATCTCTGAGTCAGCT, identical to nucleotides 76-101 and 0198 noted above, which is also complementary to the rat $D_{3}$ nucleotides $400-423$. The $\mathrm{D}_{4}$ primers (0415, o416, 0474) were as described (O'Malley et al., 1992). The $D_{5}\left(D_{1 B}\right)$ primers were derived from Tiberi et al. (1991) and included 0644, 5'-ACTGGGACCCGCGCAGGT, identical to nucleotides 99-1 19 and 0643 , the sequences of which are conserved between the $D_{1}$ and $D_{5}$ receptors (nucleotides $346-365$ of the rat $D_{5}$ receptor; Tiberi et al., 1991). The DARPP-32 primers were 5'-CTGTGCCTATACGCCCCCATC and 5'-GGGATGCTGAGGTTCCTCTCCAGGCTCAC

RNA preparation and standardization were exactly as described by Mack et al. (1991). PCR amplification and analysis were as described by O'Malley et al. (1990, 1992) for the $\mathrm{D}_{2}$ and $\mathrm{D}_{4}$ receptors, respectively. Temperatures for the $\mathrm{D}_{3} \mathrm{PCR}$ protocols were $93^{\circ} \mathrm{C}$ for $90 \mathrm{~s}, 61^{\circ} \mathrm{C}$ for $60 \mathrm{~s}$, and $72^{\circ} \mathrm{C}$ for $90 \mathrm{~s}$. The $\mathrm{D}_{1}$ and $\mathrm{D}_{5}$ parameters were $93^{\circ} \mathrm{C}$ for $60 \mathrm{~s}$, $54^{\circ} \mathrm{C}$ for $60 \mathrm{~s}$, and $72^{\circ} \mathrm{C}$ for $60 \mathrm{~s}$. The DARPP-32 parameters were $94^{\circ} \mathrm{C}$ for $60 \mathrm{~s}, 60^{\circ} \mathrm{C}$ for $60 \mathrm{~s}$, and $72^{\circ} \mathrm{C}$ for $90 \mathrm{~s}$. Oligonucleotides were endlabeled and then added to the PCK mixtures. Each template and primer set was optimized to ensure linearity of exposure. PCR products were separated on a $5 \%$ polyacrylamide gel which was subsequently dried and exposed to $\mathrm{x}$-ray film. Three cell lines (X57, X58, and X62) were selected for further characterization based on their expression of dopamine receptor mRNA.

Adenylate cyclase assay. Assays of receptor-mediated adenylate cyclase activity in corpus striatum hybrid cell membranes were modified from the original methodology (Childers, 1985) using ${ }^{3} \mathrm{H}-\mathrm{ATP}$ as a substrate. The ${ }^{3} \mathrm{H}$-cyclic AMP reaction product was quantitated by $\mathrm{HPLC}$ as described by Childers (1985). Previously frozen $\left(-70^{\circ} \mathrm{C}\right)$ tissue was homogenized in 50 volumes of ice-cold $50 \mathrm{~mm}$ Tris buffer (pH 7.7 at $4^{\circ} \mathrm{C}$ ) with $2 \mathrm{~mm}$ EGTA and $5 \mathrm{mM} \mathrm{MgCl}_{2}$, with a glass-teflon homogenizer. Homogenates were centrifuged at $43,000 \times \mathrm{g}$ for $20 \mathrm{~min}$. The resultant pellets were resuspended in adenylate cyclase buffer $(50 \mathrm{~mm}$ Tris- $\mathrm{HCl}$ with $5.0 \mathrm{~mm} \mathrm{MgCl}_{2}$, and $2 \mathrm{~mm} \mathrm{EGTA,} \mathrm{pH} \mathrm{7.4)} \mathrm{and} \mathrm{kept} \mathrm{on}$ ice prior to use for adenylate cyclase assays. The membrane preparations were incubated with reaction mixture (160 $\mu$ l) which contained $30 \mu \mathrm{M}$ cyclic AMP, $10 \mu \mathrm{M}$ ATP, $3 \mu \mathrm{M}$ isobutylmethylxanthine, $5 \mathrm{~mm}$ creatine phosphate, $25 \mathrm{U} / \mathrm{ml}$ of creatine phosphokinase, $20 \mu \mathrm{M}$ GTP, $0.04 \%$ bovine serum albumin, and $1 \mu \mathrm{Ci}{ }^{3} \mathrm{H}$-ATP together with $25-50 \mu \mathrm{g}$ membrane protein and various drug additions to a total volume of 240 $\mu$. The reaction was initiated by the addition of the ${ }^{3} \mathrm{H}-\mathrm{ATP}$, incubated at $30^{\circ} \mathrm{C}$ for $10 \mathrm{~min}$, and terminated by placing the tubes in a boiling water bath for $2 \mathrm{~min}$. The tubes were cooled on ice for $5 \mathrm{~min}$ and 0.75 units of adenosine deaminase was added. After a 5 min incubation at $30^{\circ} \mathrm{C}$, the tubes were transferred onto ice and the excess remaining ${ }^{3} \mathrm{H}$ - 
ATP was removed by the addition of $\mathrm{Ba}(\mathrm{OH})_{2}$ and $\mathrm{ZnSO}_{4}$, with 5 min between each addition. Blank levels were determined by boiling the tissue for $5 \mathrm{~min}$ before continuing with the assay. The tubes were centrifuged at $10,000 \times g$ for $15 \mathrm{~min}$, and the supernatants transferred into a parallel set of tubes for automatic sample injection into the HPLC column. Each tube was run in triplicate and the means of the control and experimental tubes compared by a paired sample $t$ test.

HPLC apparatus (Beckman model 110B pump) was connected to a Rainin Microsorb $3 \mu \mathrm{m} \mathrm{C}-18$ reverse-phase column together with a $\mathrm{C}-18$ guard column. Mobile phase consisted of $0.8 \mathrm{~m}$ sodium acetate, pH 5.0 , with $12 \%$ methanol at a flow rate of $1 \mathrm{ml} / \mathrm{min}$. Samples were injected ( $220 \mu 1$ volume) by a Spark Holland Marathon Autosampler which maintained sample temperature at $5-10^{\circ} \mathrm{C}$. The cyclic AMP peak eluted $4.1 \mathrm{~min}$ after injection and was collected by a Varex model SF2120 fraction collector. Unlabeled cyclic AMP was detected at 254 $\mathrm{nm}$ through an $8 \mu$ l flow cell (Beckman Model 153 UV Detector) with a sensitivity of $0.16 \mathrm{AU}$ full scale. ${ }^{3} \mathrm{H}$-cyclic AMP, collected in three fractions of $0.25 \mathrm{ml}$, was transferred to a glass scintillation vial to which $8 \mathrm{ml}$ of CytoScint scintillation fluid (ICN Biomedicals) was then added. Radioactive decay was measured on a Beckman LS liquid scintillation counter at an efficiency or $45 \%$.

Under these conditions, more than $90 \%$ of the cyclic AMP was recovered as determined from studies using added ${ }^{3} \mathrm{H}$-cyclic AMP.

Aggregation. The ability of the hybrid cells to aggregate in rotationmediated cell culture was tested as described by Choi et al. (1991), adapted from the procedure described by Moscona (1961) for examining cell-cell interactions. After $36 \mathrm{hr}$ in culture, the aggregated cells were transferred to a depression slide and photographed.

Differentiation and immunocytochemistry. The clonal hybrid cell lines $\mathrm{X} 57, \mathrm{X} 58$, and X62 and the parent neuroblastoma line N18TG2 were plated at a density of $5-20 \times 10^{4}$ cells per $60 \mathrm{~mm}$ culture dish. The cells were maintained in culture for up to $5 \mathrm{~d}$ in the presence of $1 \mathrm{~mm}$ n-butyric acid, which causes some cultured cells to differentiate (Prasad and Sinha, 1976; Choi et al., 1991), or $10 \mu \mathrm{M}$ forskolin, which maximally stimulates adenylate cyclase activity, or vehicle $(0.1 \%$ dimethylsulfoxide). Cultures were examined for the expression of the neuronal marker neurofilament protein (NFP) and a glial marker, glial fibrillary acidic protein (GFAP). Immunostaining was performed according to the peroxidase-antiperoxidase method of Sternberger (1979) as described previously (Choi et al., 1991). The antibodies used were the monoclonal antibody $4.3 \mathrm{~F}_{9}$, which reacts with the carboxyl-terminal domains of the high-molecular-weight neurofilament subunits NF150 and NF200 NFP, as well as $2.2 \mathbf{B}_{10.6}$ directed against GFAP (Trojanowski et al., 1983).

Protein determination. Proteins were determined using the commercially available Pierce assay (Pierce, Rockford, IL) with bovine serum albumin as a standard.

Data analysis. Saturation isotherms were fitted by a single-site model. Radioligand affinity $\left(\mathrm{K}_{\mathrm{d}}\right)$ and the density of binding sites $\left(\mathrm{B}_{\max }\right)$ were obtained using weighted Eadie-Hofstee plots as described by Zivin and Waud (1982). Computer-assisted analysis of ${ }^{3} \mathrm{H}-\mathrm{SCH} 23390$ and ${ }^{3} \mathrm{H}-$ spiperone binding isotherms indicated a single, saturable site of interaction. Specific binding ranged from 50 to $80 \%$, varying as a function of the concentration of radioligand and density of binding sites.

\section{Results}

Twenty-seven immortalized monoclonal corpus striatum hybrid cell lines were generated from the cell population E1X. The properties of four of the most extensively characterized monoclonal hybrid cell lines (X52, X57, X58, and X62) are summarized in Table 1.

\section{Neurochemical characterization of immortalized monoclonal corpus striatum hybrid cell lines}

GABA levels were measured in three monoclonal cell lines (X57, $\mathrm{X} 58$, and X62). None of these cell lines demonstrated GABA levels signiticantly different from that detected in either the N18TG2 parent cell line $(1.36 \pm 0.07 \mu \mathrm{g} / \mathrm{mg}$ protein, $n=4)$ or the cell population (E1X) from which the hybrid cells were derived $(1.22 \pm 0.16 \mu \mathrm{g} / \mathrm{mg}$ protein, $n=5)$.

The cell lines subcloned from the E1X cell population were also screened for the expression of the cholinergic marker ChAT.
Table 1. Characterization of monoclonal hybrid cell lines derived from somatic cell fusion of embryonic corpus striatum with N18TG2 neuroblastoma cells

\begin{tabular}{|c|c|c|c|c|c|}
\hline \multirow[b]{2}{*}{ Property } & \multicolumn{5}{|l|}{ Cell line } \\
\hline & N18TG2 & $\times 52$ & $\times 57$ & $\mathrm{X} 58$ & $\mathrm{X} 62$ \\
\hline Neurite formation & - & & + & + & + \\
\hline Aggregate formation & - & + & + & + & + \\
\hline \multicolumn{6}{|l|}{ Immunocytochemistry } \\
\hline NFP & - & + & + & + & + \\
\hline GFAP & - & - & - & - & - \\
\hline \multicolumn{6}{|l|}{ Neurochemistry } \\
\hline ChAT activity & - & + & + & + & + \\
\hline $\mathrm{ACh}$ & - & + & - & + & - \\
\hline GABA & & & $\#$ & $\#$ & $\#$ \\
\hline \multicolumn{6}{|c|}{ Dopamine receptor mRNA } \\
\hline D1 & - & + & + & - & + \\
\hline D2 & - & + & + & + & - \\
\hline D3 & - & - & - & - & - \\
\hline $\mathrm{D} 4^{a}$ & + & - & + & + & + \\
\hline D5 & - & - & + & - & + \\
\hline \multicolumn{6}{|c|}{ Functional dopamine receptors } \\
\hline D1 & - & & + & - & + \\
\hline D2 & - & & - & + & - \\
\hline DARPP-32 mRNA & $+a$ & + & + & + & + \\
\hline
\end{tabular}

Summary of the properties of selected corpus striatum hybrid lines. Symbols: + , presence of trait; - , absence of trait; spaces, line has not been examined for trait; \#, not significantly different from N18TG2 parent cells.

"Trace only; detected after $4 \mathrm{~d}$ exposure of autoradiograms.

The results of these experiments are shown in Figure 1. The original cell population (E1X) from which these cell lines were subcloned expressed higher levels of ChAT activity $(161.29 \pm$ $14.6 \mathrm{pmol} / \mathrm{min} / \mathrm{mg}$ protein) than some of the subclones examined. Most of the monoclonal hybrid cell lines examined expressed levels of ChAT activity comparable to that observed in the parent N18TG 2 cells (see Fig. 1). In contrast, a number of monoclonal cell lines (X52, X58) expressed substantial levels of enzyme activity ranging from $5.5 \pm 0.3$ to $921.3 \pm 97.4$ $\mathrm{pmol} / \mathrm{min} / \mathrm{mg}$ protein (X52).

Endogenous ACh levels were measured (Table 2) in two monoclonal cell lines which expressed high levels of ChAT activity (X52 and X58). Both the X52 (49.64 $\pm 4.23 \mathrm{ng} / \mathrm{mg}$ protein) and $X 58(1.78 \pm 0.07 \mathrm{ng} / \mathrm{mg}$ protein) cells contained detectable endogenous levels of $\mathrm{ACh}$. Under these conditions no ACh was detected in the X57 or X62 cell lines, although each of these cell lines demonstrated ChAT activity higher than that observed in the N18TG2 cells. No $\mathrm{ACh}$ was detected in the N18TG2 neuroblastoma. The 20-fold greater levels of $\mathrm{ACh}$ in $\mathrm{X} 52$ and $\mathrm{X} 58$ were not correlated with the absolute difference in ChAT activity in the two cell lines.

\section{Dopamine receptor and DARPP-32 $m R N A$ expression in immortalized monoclonal corpus striatum hybrid cell lines}

The expression of $\mathrm{D}_{1}, \mathrm{D}_{2}, \mathrm{D}_{3}, \mathrm{D}_{4}$, and $\mathrm{D}_{5}$ dopamine receptor mRNA and DARPP-32 mRNA was analyzed using reverse transcription (RT) PCR. For each transcript, standardized RNAs prepared from the hybrid cells were processed simultaneously to allow for direct comparison of band intensities. An arbitrary scale of $1+$ to $4+$ was chosen to represent the relative intensity 


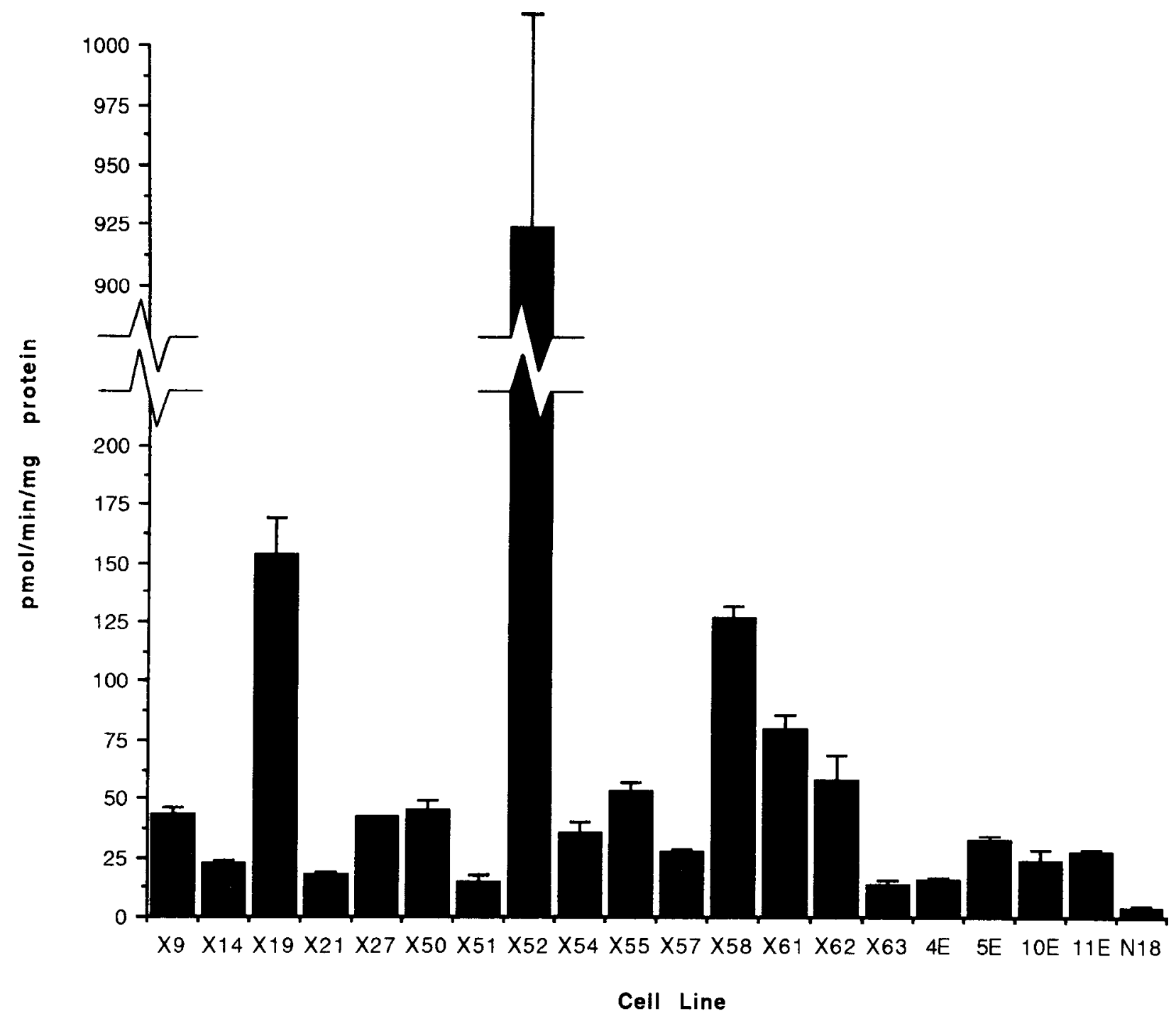

Figure 1. Choline acetyltransferase (ChAT) activities (picomoles of ACh formed per minute per milligram of protein) of E18 corpus striatum hybrid cell lines and the parent N18TG2 neuroblastoma cells. Corpus striatum hybrid cell lines expressing less than $15 \mathrm{pmol} / \mathrm{min} / \mathrm{mg}$ protein of ChAT activity are not represented in this figure. The values shown are means $\pm \operatorname{SEM}(n=3)$.

of individual bands. The results from this analysis for each receptor subtype and DARPP-32 are presented in Table 3. Representative autoradiograms for the $D_{1}$ receptor are shown in Figure 2. As indicated, no $\mathrm{D}_{3}$ mRNA was detected in any of the monoclonal cell lines. Low levels of $\mathrm{D}_{4} \mathrm{mRNA}$ were detected in all the cell lines except $X 52$, albeit with very long exposure times $(4 \mathrm{~d})$. Although $\mathrm{D}_{4}$ receptor mRNA was present, this amount of message is apparently insufficient for detectable protcin expression by radioligand binding assays since subsequent experiments could detect no specific binding. Most of the cell lines express a combination of receptor mRNA transcripts. However, several monoclonal lines appear to express only one receptor subtype other than $D_{4}$. For example, the cell lines $4 E$, $5 \mathrm{E}, 9 \mathrm{E}, 10 \mathrm{E}, 11 \mathrm{E}, \mathrm{X} 1, \mathrm{X} 14$, and $\mathrm{X} 15$ express only the $\mathrm{D}_{1}$ transcripts. The X21 and X58 cells express only $D_{2}$ mRNA, and one cell line (3E) appears devoid of all dopamine receptors except for trace levels of the $\mathrm{D}_{4}$ transcript. Negligible levels of DARPP-32 mRNA (Table 3) were detected in the parent N18TG2 cells and the cell population (E1X) from which the monoclonal lines were generated. Some of the monoclonal cell lines (3E, X1, X4, X9, X17, X21) expressed a trace or no transcript. Other monoclonal hybrid cell lines $(5 \mathrm{E}, 9 \mathrm{E}, 10 \mathrm{E}, 11 \mathrm{E})$ expressed a robust signal. $\mathrm{D}_{2}$ dopamine receptor mRNA has also been detected by Northern blot analysis in some of the monoclonal hybrid cell lines (J. S. Fink, personal communication). In addition, in the corpus striatum hybrid cell line X57, by RT-PCR techniques using a range of primer sets which amplify both the $5^{\prime}$ untranslated region and other regions of this transcript it has been possible to demonstrate the presence of bands consistent in size with $D_{1}$ receptor mRNA, indicating that this cell line does contain a full-length mRNA transcript encoding the $D_{1}$ receptor.

$D_{1}$ and $D_{2}$ dopamine receptor binding site expression in immortalized monoclonal corpus striatum hybrid cell lines

Based on the high levels of ChAT activity and expression of dopamine receptor mRNA observed in subclones X57, X58, and $X 62$, these monoclonal cell lines were then examined for 


\begin{tabular}{lc}
$\begin{array}{l}\text { Table 2. } \\
\text { and corpus striatum hybrid cell lines }\end{array}$ \\
$\begin{array}{ll}\text { Endogenous ACh levels } \\
\text { (ng/mg protein) }\end{array}$ \\
\hline X52 & $49.64 \pm 4.23$ \\
X58 & $1.78 \pm 0.07$ \\
X57 & Not detected \\
X62 & Not detected \\
N18TG2 & Not detected
\end{tabular}

$\overline{\mathrm{ACh}}$ levels in cell homogenates were quantitated by high-pressure liquid chromatography with electrochemical detection. Values represent the mean \pm SEM $(\mathrm{X} 52, n=5 ; \mathrm{X} 58, n=3)$.

the expression of $D_{1}$ and $D_{2}$ dopamine receptor binding sites.

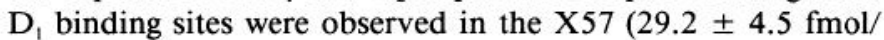
mg protein) and $\mathrm{X} 62(43.8 \pm 6.8)$ cells, but no $\mathrm{D}_{2}$ binding sites were detected. The affinity $\left(\mathrm{K}_{\mathrm{d}}\right)$ of the radioligand for these $\mathrm{D}_{1}$ sites was $0.24 \pm 0.02 \mathrm{nM}$ (X57) and $0.23 \pm 0.06 \mathrm{nM}$ (X62). In the case of the cell line X58, which expressed only the $\mathrm{D}_{2}$ transcript (Table 3$), \mathrm{D}_{2}$ binding sites were observed $(80.9 \pm 9.8$ $\mathrm{fmol} / \mathrm{mg}$ protein). The affinity of the radioligand for the $\mathrm{D}_{2}$ binding sites was $0.08 \pm 0.01 \mathrm{~nm}$.

$D_{1}$ and $D_{2}$ dopamine receptor-linked adenylate cyclase activity in immortalized monoclonal corpus striatum hybrid cell lines

Given the presence of $D_{1}$ and $D_{2}$ dopamine receptor binding sites in the hybrid cell lines, studies were conducted to determine whether these receptors were functional by examining their ability to modulate adenylate cyclase (AC) activity (Table 4). $\mathrm{D}_{1}$ receptor-mediated modulation of AC activity was observed in both the X57 and X62 lines in the presence of a specific $D_{1}$ agonist $[\mathrm{R}(+) \mathrm{SKF} 38393,10 \mu \mathrm{M}]$. This stimulation was blocked by the addition of a specific $D_{1}$ antagonist $\left(S C H\right.$ 23390). $D_{2}$ receptor-mediated attenuation of forskolin-induced AC activity was detected in the X 58 line and was abolished by preincubation with a $\mathrm{D}_{2}$ receptor antagonist, eticlopride, suggesting that the effect is mediated by $\mathrm{D}_{2}$ receptor. No receptor-linked stimulation of adenylate cyclase activity was observed in the N18TG2 cells under these conditions.

\section{Cell morphology, growth characteristics, and expression of cytoskeletal markers in immortalized monoclonal corpus striatum hybrid cell lines}

In monolayer cultures, lines X57 and X58 grew as clusters of cells connected by a network of processes (Fig. $3 A, B$ ). The hybrid $\mathrm{X} 62$ cell line grew as a flat monolayer of cells (Fig. $3 C$ ). The neuroblastoma cells had flat somata, short processes, and were dispersed as a monolayer (Fig. $3 F$ ). The population-doubling time of the hybrid cells and the N18TG2 cells was approximately $24 \mathrm{hr}$. The neuronal character of the hybrid cell morphology was examined by screening these cells for neurofilament expression, a specific marker for neurons (Lee et al., 1982). Following treatment for $48 \mathrm{hr}$ with forskolin (Fig. $3 D$ ) or for 1 week with butyric acid (Fig. $3 E$ ), the hybrid lines, but not the N18TG2 cells, expressed prominent, neurite-like processes which reacted with monoclonal antibody $4.3 \mathrm{~F}_{9}$ to neurofilament units NF150 and NF200. Photomicrographs (Fig. 3D,E) are shown for differentiated X57 cells only, although a similar response was observed in both the X 58 and X62 cells. Neither the hybrid nor the neuroblastoma cells in the presence of either forskolin
Table 3. Dopamine receptor subtype and DARPP-32 mRNA expression in monoclonal hybrid corpus striatum cell lines

\begin{tabular}{|c|c|c|c|c|c|c|}
\hline \multirow[b]{2}{*}{ Cell line } & \multicolumn{6}{|l|}{ mRNA } \\
\hline & $\mathrm{D}_{1}$ & $\mathrm{D}_{2}$ & $\mathrm{D}_{3}$ & $\mathrm{D}_{4}{ }^{a}$ & $\mathrm{D}_{5}$ & DARPP-32 \\
\hline N18TG2 & - & - & - & + & - & $\operatorname{tr}$ \\
\hline $\mathrm{X} 1$ & + & - & - & + & - & $\operatorname{tr}$ \\
\hline $\mathrm{X} 4$ & + & + & - & + & - & - \\
\hline $\mathrm{X} 9$ & + & + & - & + & - & $\operatorname{tr}$ \\
\hline $\mathrm{X} 13$ & + & + & - & + & - & ++ \\
\hline $\mathrm{X} 14$ & + & - & - & + & - & + \\
\hline $\mathrm{X} 15$ & + & - & - & + & - & + \\
\hline $\mathrm{X} 17$ & + & + & - & + & - & $\mathrm{tr}$ \\
\hline $\mathrm{X} 18$ & + & + & - & + & - & + \\
\hline $\mathrm{X} 19$ & ++ & + & - & + & - & ++ \\
\hline $\mathrm{X} 21$ & - & + & - & + & - & - \\
\hline$\times 24$ & ++ & + & - & + & - & + \\
\hline $\mathrm{X} 27$ & ++ & + & - & + & + & ++ \\
\hline $\mathrm{X} 50$ & ++ & + & - & + & + & + \\
\hline X51 & + & + & - & + & + & ++ \\
\hline X52 & ++ & + & - & - & - & + \\
\hline X54 & ++ & + & - & + & + & ++ \\
\hline X55 & + & + & - & + & - & + \\
\hline X57 & ++++ & + & - & + & + & ++ \\
\hline X58 & - & ++ & - & + & - & ++ \\
\hline X61 & ++ & - & - & + & + & ++ \\
\hline X62 & + & - & - & + & + & ++ \\
\hline $\mathrm{X} 63$ & - & + & - & + & + & + \\
\hline $3 \mathrm{E}$ & - & - & - & + & - & $\operatorname{tr}$ \\
\hline $4 \mathrm{E}$ & ++ & - & - & + & - & ++ \\
\hline $5 \mathrm{E}$ & + & - & - & + & - & +++ \\
\hline $9 \mathrm{E}$ & + & - & - & + & - & +++ \\
\hline $10 \mathrm{E}$ & + & - & - & + & - & +++ \\
\hline $11 \mathrm{E}$ & + & - & - & + & - & +++ \\
\hline
\end{tabular}

The expression of $\mathrm{D}_{1}, \mathrm{D}_{2}, \mathrm{D}_{3}, \mathrm{D}_{4}$, and $\mathrm{D}_{3}$ dopamine receptor and dopamine- and adenosine $3^{\prime}: 5^{\prime}$-monophosphate-regulated phosphoprotein, $M_{r}$ 32,000 (DARPP32), mRNA was examined in monoclonal striatal hybrid cell lines using reverse transcription polymerase chain reaction techniques. An arbitrary scale of + to ++++ was chosen to represent the relative intensity of individual bands.

${ }^{a}$ Detected only after $4 \mathrm{~d}$ of exposure. tr, trace.

or butyric acid stained with the monoclonal antibody $2.2 \mathrm{~B}_{10.6}$ to glial fibrillary acidic protein.

The monoclonal hybrid cell lines were examined for their ability to form aggregates in a three-dimensional rotation-mediated culture system. In the cell reaggregation system as described by Moscona (1961), N18TG2 cells (Fig. 4D) showed minimal aggregation. However, each of the corpus striatum hybrid cell lines examined (X52, X57, X58, and X62) exhibited reasonably well formed aggregates (Fig. $4 A-C$ ), whose mor-

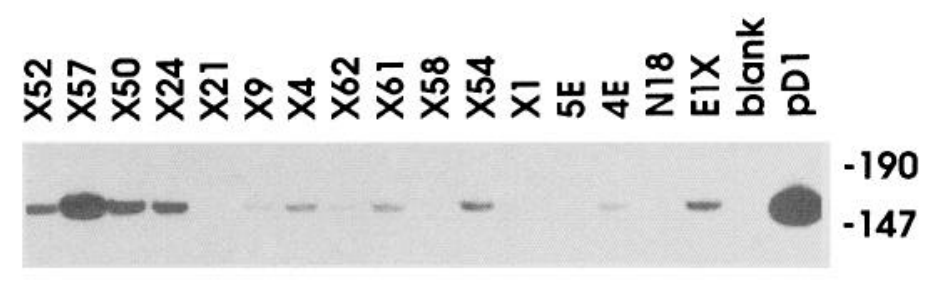

Figure 2. Representative autoradiograms of the reverse transcriptionpolymerase chain reaction (RT-PCR) $\mathrm{D}_{1}$ dopamine receptor products from monoclonal hybrid corpus striatum cell lines. 

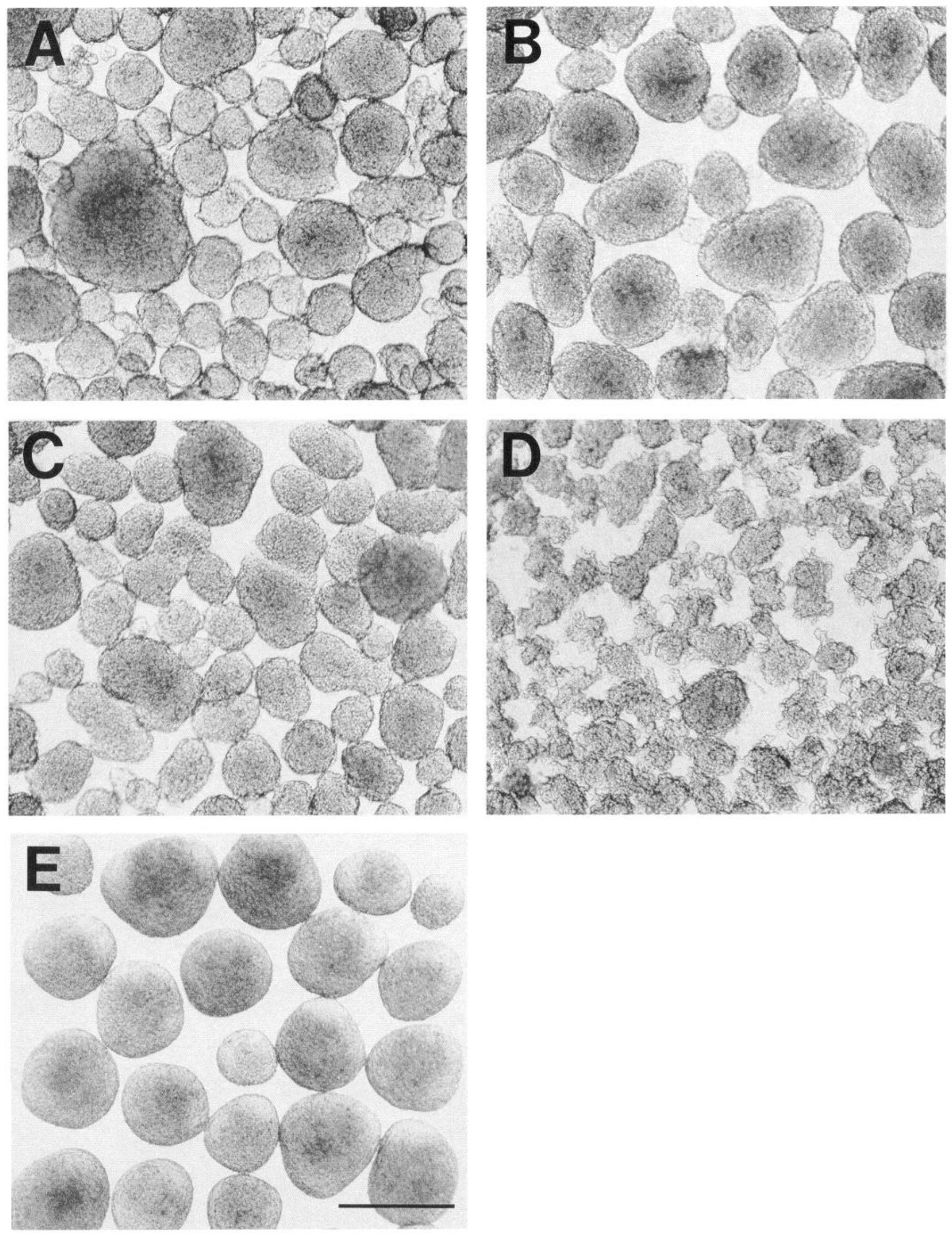
Table 4. $D_{1}$ and $D_{2}$ dopamine receptor-linked modulation of adenylate cyclase activity in monoclonal hybrid corpus striatum cell lines

\begin{tabular}{|c|c|c|c|c|c|c|}
\hline \multirow{2}{*}{$\begin{array}{l}\text { Assay } \\
\text { condition }\end{array}$} & \multicolumn{6}{|l|}{ Cell line } \\
\hline & N18TG2 & $\mathrm{X} 57$ & $\mathrm{X} 62$ & $\times 57$ & $\mathrm{X62}$ & $\mathrm{X58}$ \\
\hline Control & $7.3 \pm 1.6$ & $5.3 \pm 2.6$ & $17.4 \pm 5.2$ & $10.4 \pm 2.9$ & $8.8 \pm 1.3$ & $7.6 \pm 4.5$ \\
\hline SKF38393 & $6.5 \pm 1.7$ & $6.8 \pm 3.7^{f}$ & $24.5 \pm 5.9^{a}$ & - & - & - \\
\hline $\begin{array}{l}\text { SKF38393 } \\
\quad+\text { SCH } 23390\end{array}$ & - & $5.4 \pm 2.9^{b}$ & $19.0 \pm 5.1^{b}$ & - & - & - \\
\hline Forskolin & $13.0 \pm 3.2^{a}$ & - & - & $23.6 \pm 4.7^{a}$ & $28.7 \pm 4.8^{a}$ & $17.4 \pm 7.7^{f}$ \\
\hline $\begin{array}{l}\text { Forskolin } \\
\quad+\text { quinpirole }\end{array}$ & $13.9 \pm 3.4^{a, c}$ & - & - & $24.1 \pm 4.5^{a . f}$ & $28.8 \pm 4.8^{a . c}$ & $11.5 \pm 5.2^{c}$ \\
\hline $\begin{array}{l}\text { Forskolin } \\
\quad+\text { quinpirole } \\
\quad+\text { eticlopride }\end{array}$ & - & - & - & - & - & $15.6 \pm 6.3^{d e}$ \\
\hline
\end{tabular}

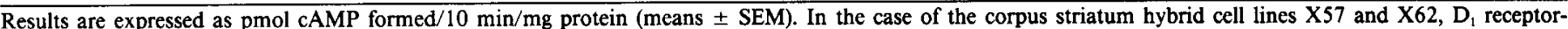

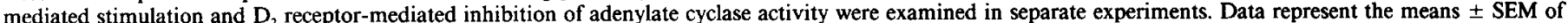

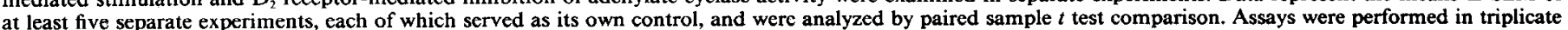

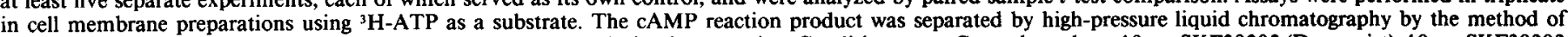

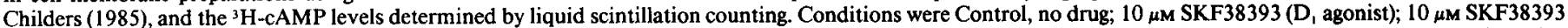

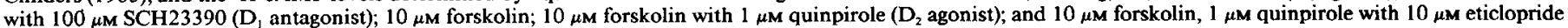
$\left(\mathrm{D}_{2}\right.$ antagonist).

- , not determined.

- Values are significantly different from control levels as determined by paired sample $t$ test $(p<0.01)$.

$b$ Values are significantly different from SKF38393 alone as determined by paired sample $t$ test $(p<0.05)$.

- Values are significantly different from forskolin alone as determined by paired sample $t$ test $(p<0.05)$.

$d$ Values are significantly different from forskolin with quinpirole as determined by paired sample $t$ test $(p<0.05)$.

- Values are not significantly different from forskolin alone.

$f$ Values are significantly different from control as determined by paired sample $t$ test $(p<0.05)$.

phology resembled that of aggregates of primary striatal cells (Fig. $4 E$ ), within $36 \mathrm{hr}$, a finding also observed with dopaminergic hybrid cell lines derived from embryonic murine rostral mesencephalic tegmentum (Choi et al., 1991) and septal cholinergic cell lines (Hammond et al., 1986).

\section{Discussion}

Immortalized monoclonal corpus striatum hybrid cell lines possessing properties characteristic of corpus striatum neurons have been generated by fusing embryonic day 18 corpus striatal cells with an HPRT-deficient murine neuroblastoma cell line (N18TG2). The monoclonal cell lines obtained appear to be hybrids of N18TG2 cells and striatal neurons since: (1) the cells survive and multiply in HAT medium, which selects against unfused neuroblastoma cells devoid of the HPRT enzyme; (2) the primary brain cells used as fusion partners are postmitotic and are incapable of multiplication, and for that reason are eliminated in the single-cell cloning procedure; (3) the immortalized cells form aggregates in rotatory culture with a morphology similar to that of primary cells (Fig. 4), while neuroblastoma cells do not share this property; and (4) the hybrid cells elaborate neurite-like processes in the presence of n-butyric acid or forskolin, which react to the neurofilament protein-specific antibody $4.3 \mathrm{~F}_{9}$ (Fig. 3). There was no detectable labeling of these processes under control or differentiating conditions with an antibody directed against glial fibrillary acidic protein. Under the same conditions, no immunoreactivity for NFP or GFAP was observed in the N18TG2 cells.

The monoclonal cell lines express an array of $D_{1}, D_{2}, D_{4}$, and $\mathrm{D}_{s}$ dopamine receptor mRNA in various combinations (Table 3). The majority of these lines also express varying amounts of mRNA for the medium spiny neuron $D_{1}$ receptor-specific marker DARPP-32. Of the lines selected for more detailed characterization, two (X57 and X62) were demonstrated to have functional $D_{1}$ receptors and one line $(X 58)$ had functional $D_{2}$ receptors. While all four of the lines expressed ChAT activity, a feature characteristic of large corpus striatum interneurons, only two of the lines (X52 and X58, Table 2) actually synthesized detectable amounts of acetylcholine.

While these hybrid cell lines express a variety of neurochemical markers characteristic of striatal neurons, it is not possible to identify a single neuronal parent for each of the monoclonal lines. The majority of the neuronal population of the corpus striatum is comprised of medium spiny neurons, which are the principal output cells of the corpus striatum and contain GABA (Graybiel and Ragsdale, 1983; Gerfen et al., 1987; Gerfen, 1988, 1992; Graybiel, 1990). The anatomic and functional compartmentalization of these cells has been defined by their afferent projections (to the globus pallidus and substantia nigra pars reticulata) and their neurochemistry. The GABAergic medium

$\leftarrow$

Figure 3. Photomicrographs of selected corpus striatum monoclonal hybrid cell lines stained immunocytochemically for neurofilament protein (NFP). $A$, Undifferentiated X 57 hybrid cells. $B$, Undifferentiated X 58 hybrid cells. $C$, Undifferentiated X62 hybrid cells. $D$, X 57 hybrid cells differentiated with forskolin. $E$, X57 hybrid cells differentiated with n-butyric acid. $F$, Undifferentiated N18TG2 cells. Differential interference optics were used to visualize the unstained somata and processes that were not well visualized under bright-field optics. Note the absence of NFP staining in the N18TG2 neuroblastoma $(F)$ compared to the hybrid cells $(A-E)$. Both the hybrid cell lines X58 and X62, but not the N18TG2 cells, exhibited similar morphological responses (extension of neurite-like processes) and NFP immunoreactivity when differentiated under the same treatment conditions. Scale bar, $100 \mu \mathrm{m}$. 

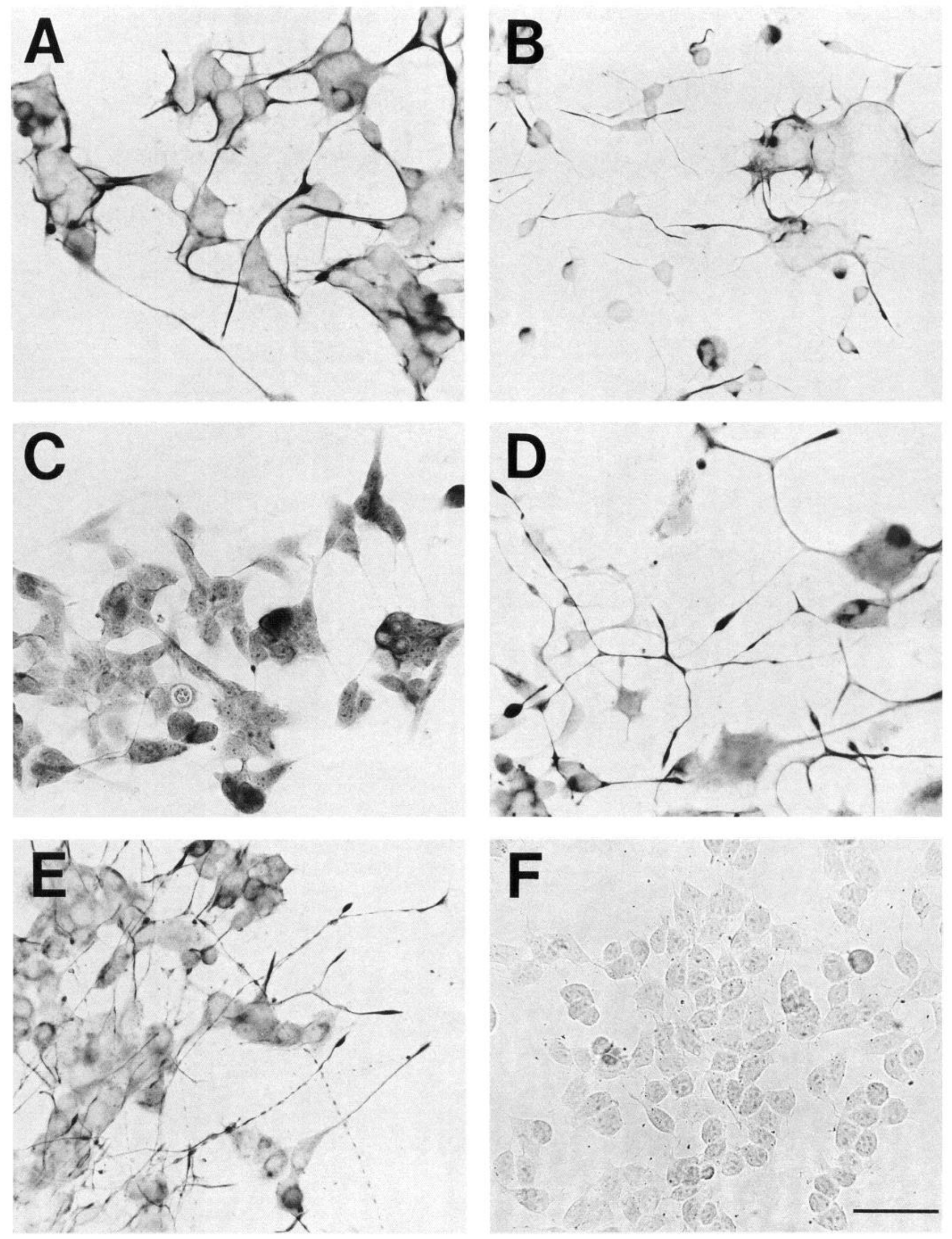
spiny neuron population accounts for approximately $90 \%$ of the cell population (Kita and Kitai, 1988). The remainder of the neuronal population within the corpus striatum is comprised of larger neurons. These include large, aspiny cholinergic interneurons as well as some medium aspiny neurons which contain GABA (Bolam et al., 1985) or somatostatin (DiFiglia and Aronin, 1982).

The precise distribution of dopamine receptor subtypes within corpus striatum neuronal populations has not yet been resolved (Gerfen, 1992; Surmeier et al., 1993). $D_{1}$ receptors have been localized principally to dynorphin and substance P-containing striatonigral medium spiny neurons (Gerfen et al., 1990; Le Moine et al., 1990), and possibly some cholinergic interneurons (Bernard et al., 1992). $\mathrm{D}_{2}$ receptors are present on striatopallidal, enkephalinergic medium spiny neurons and large cholinergic interneurons, as well as in a noncholinergic neuronal population (Fink et al., 1992). Several lines of evidence suggest that $D_{1}$ and $D_{2}$ receptors may be coexpressed within the same corpus striatum neuron. Studies of the synergistic interactions between $D_{1}$ and $D_{2}$ receptors with respect to $\left(\mathrm{Na}^{+}+\mathrm{K}^{+}\right)$ATPase activity (Bertorello et al., 1990) have suggested that these receptors may be coexpressed in the same cells. Using RT-PCR techniques, Surmeier et al. (1992) have described the coexpression of $\mathrm{D}_{1}, \mathrm{D}_{2}$, and $\mathrm{D}_{3} \mathrm{cDNA}$ in single striatal neurons. In situ hybridization studies (Lester et al., 1993) indicate that $D_{1}$ and $\mathrm{D}_{2}$ receptor mRNA may be coexpressed in approximately $26 \%$ of the neurons of the corpus striatum. Therefore, the neuronal parent of a monoclonal hybrid cell line cannot be identified by the expression of a specific dopamine receptor.

The nature of the fusion process, itself, is such that the cell lines obtained are heterogenous in nature. It is likely that chromosomes from more than one primary cell type may be incorporated in the final fusion product and that chromosomes are also lost in the fusion process (Killary and Fournier, 1984). The monoclonal hybrid cell lines described here in all probability contain an admixture of chromosomes resulting from the fusion of one or more primary corpus striatum cells with the neuroblastoma. The somatic cell fusion process may capture either components of biochemically disparate cell types or partially capture components of a single cell type. For example, we have described (Choi et al., 1991) a hybrid cell line, MN9D, which produces and stores dopamine. Another line, MN9H, produced in the same fusion, synthesizes dopamine but apparently lacks adequate storage mechanisms for the neurotransmitter, probably due to a failure to incorporate necessary chromosomal material into the final fusion product. Given these considerations, it is clearly not possible to ascribe all of the characteristics of a given hybrid cell line to the exclusive participation of any particular subset of striatal neurons in the fusion process. Nevertheless, considering the expression of specific neurochemical markers, including ChAT, ACh, dopamine receptors, and DARPP-32 mRNA in the immortalized monoclonal hybrid cell lines, it is probable that corpus striatum medium spiny neurons and cholinergic interneurons participated in the fusion process.

It is interesting that despite the preponderance of GABA- expressing medium spiny neurons in the corpus striatum, no GABAergic hybrid cell lines were generated from the fusion process. It seems likely that medium spiny neurons did participate in the fusion process, given the large numbers of cells of this type in the striatum and the presence of mRNA for DARPP32 , a marker for such cells, in many of the monoclonal hybrid cell lines. However, since the hybrid cell lines are subclones from a small population of cells which survived treatment with $\mathrm{n}$-butyric acid and a specific $\mathrm{D}_{1}$ agonist, it is possible that the lines were obtained from corpus striatum cells which, in fact, did not express GABA. Another possibility is that the fusion process itself may have either excluded chromosomal material necessary for GABA synthesis or repressed the expression of the GABAergic phenotype of medium spiny neurons which participated in the fusion.

In contrast to the absence of GABA, substantial levels of ChAT activity were detected in the cell population (E1X) from which the monoclonal hybrid cell lines were derived. The presence of ChAT activity and endogenous ACh (Table 2) in at least two of these lines (X52 and X58) suggests that some of these cell lines are derived, at least in part, from the cholinergic corpus striatum interneuron. The sixfold difference in ChAT activity was not correlated with the difference in $\mathrm{ACh}$ content (greater than 20 -fold) between the two cell lines. It is unlikely that the high levels of ChAT activity and the ability to synthesize $\mathrm{ACh}$ are derived from genes that are silent in the N18TG2 cell line (Mevel-Minio and Weiss, 1981; Killary and Fournier, 1984). No ChAT activity was detected in a mesencephalic dopaminergic cell line (MN9D) produced with N18TG2 as the fusion partner (Choi et al., 1992). On the other hand, the fusion of N18TG2 cells with primary septal cholinergic cells resulted in cell lines which do express ChAT activity (Hammond et al., 1986, 1990; Lee et al., 1990a), suggesting that the expression of a cholinergic phenotype in cell lines produced by the somatic cell fusion method is most likely a function of the lineage of the primary cells participating in the fusion process. In addition, neither ChAT activity nor $\mathrm{ACh}$ synthesis was detected in N18TG2 cells grown in basal medium or under differentiating conditions as reported by Blusztajn et al. (1992). Thus, the expression of ChAT activity and ACh synthesis in the hybrid cells, together with $\mathrm{K}^{+}$-evoked $\mathrm{ACh}$ release from $\mathrm{X} 52$ cells (Wainwright et al., 1993), most likely reflects the expression of $\mathrm{C} 57 \mathrm{BL} / 6 \mathrm{~J}$ genes from cholinergic interneurons of the corpus striatum.

The caudate-putamen contains the highest levels of DARPP32 phosphoprotein and DARPP-32 mRNA in the brain (Ehrlich et al., 1990; Schalling et al., 1990). Within the caudate, over $80 \%$ of the medium spiny neurons contain DARPP-32 (Hemmings and Greengard, 1986; Ehrlich et al., 1990; Ouimet and Greengard, 1990). While DARPP-32-immunoreactive cells can be demonstrated by E14 in the neostriatum (Foster et al., 1987), no mRNA is detectable prior to birth either by in situ hybridization techniques (Gustafson et al., 1992) or by Northern blot analyses (Ehrlich et al., 1990). In situ hybridization studies (Gustafson et al., 1992) indicate that DARPP-32 is not expressed in

\footnotetext{
Figure 4. Aggregate formation in the three-dimensional reaggregate culture system. Aggregates were photographed $36 \mathrm{hr}$ after the initial aggregation. $A$, X57 hybrid cells. $B, \mathrm{X} 58$ hybrid cells. $C$, X62 hybrid cells. $D$, N18TG2 cells. $E$, Primary embryonic day 14 striatal cells after $21 \mathrm{~d}$ in culture. Note the well defined morphology of the aggregates formed by hybrid cell lines $(A, B, C)$ and primary striatal cells $(E)$ comparcd to the irregular clumping observed in the N18TG2 cells $(D)$. Scale bar, $500 \mu \mathrm{m}$.
} 
cholinergic corpus striatum neurons. Therefore, the detection of DARPP-32 mRNA by RT-PCR techniques in the majority of monoclonal cell lines obtained (Table 3 ) would suggest that the medium spiny neurons of the striatum were probably frequent participants in the initial cell fusion process.

The demonstration of functional $D_{1}$ (X57 and X62) and $D_{2}$ receptors (X58) coupled to the modulation of adenylate cyclase activity in the hybrid cell lines, but not the N18TG2 cells, suggests that the expression of functional dopamine receptors in the hybrid cells is also a property derived from the corpus striatưm neuronal parent cells. No dopamine receptor mRNA, except for a trace of $D_{4}$ transcript, was detected in the N18TG2 cells. Further, we have not detected mRNA for any of the dopamine receptor subtypes in the dopaminergic cell line MN9D (Choi et al., 1991) derived from the fusion of N18TG2 cells with embryonic mouse mesencephalon (Tang et al., 1994). The density of $D_{1}$ and $D_{2}$ binding sites in the hybrid cell lines described in this report (less than $50 \mathrm{fmol} / \mathrm{mg}$ protein) is low compared to the adult rodent corpus striatum (2000 $\pm 183 \mathrm{fmol} /$ mg protein) as reported, for example, by Gelbard et al. (1989) (for review see Vadasz et al., 1992). However, the gestational age of the primary corpus striatum cells from which these hybrid lines were derived ( $E 18)$ precedes the onset of the rapid, postnatal increase in $D_{1}$ and $D_{2}$ receptor density observed in the rodent corpus striatum (Bruinink et al., 1983; Murrin and Zeng, 1986, 1990; Zeng et al., 1988; Gelbard et al., 1989; Rao et al., $1991)$ as well as the robust increase in structure and activity of dopaminergic synapses that occurs over the first four postnatal weeks (McGeer et al., 1971; Coyle and Axelrod, 1972; Porcher and Heller, 1972).

The extent of stimulation of adenylatc cyclase secn in cell lines X57 and X62 in the presence of a $D_{1}$ agonist and forskolin is also modest. There are a number of possible explanations for this observation. A modest stimulation of adenylate cyclase activity, despite the presence of a high density of receptors, is a distinctive feature of adult striatal $D_{1}$ receptor pharmacology (Battaglia et al., 1986; Mailman et al., 1986). More specifically, the monoclonal hybrid cell lines are derived from embryonic day 18 corpus striatum neurons and, therefore, may not be directly comparable to adult corpus striatum neurons with respect to dopamine receptor-mediated modulation of adenylate cyclase activity. Indeed, the twofold increase in adenylate cyclase activity in response to forskolin stimulation in the corpus striatum hybrid cell lines is comparable to that reported in other studies (Chneiweiss et al., 1988) involving embryonic murine striatal membrane preparations. While the partial $D_{1}$ receptor agonist SKF 38393 has been widely used in studies reporting the expression of functional, cloned $D_{1}$-like receptors (Dearry et al., 1990; Zhou et al., 1990; Tiberi et al., 1991), the efficacy of SKF 38393 in the examination of $D_{1}$ receptor-mediated stimulation of adenylate cyclase activity in the monoclonal hybrid cell lines may be limited by the low density of receptors in the cell lines examined. It is possible that the use of a full agonist such as fenoldopam may lead to greater expression of receptormediated stimulation of adenylate cyclase activity.

The availability of immortalized monoclonal hybrid neuronal cell lines of striatal origin provides a stable, homogenous cell population for the study of corpus striatum neurochemical properties. While cell lines from other sources (Balmforth et al., 1986, 1988; Monsma et al., 1989; Sidhu and Fishman, 1990; Ivins et al., 1991; Lovenberg et al., 1991; Steffey et al., 1991) provide models in which to examine aspects of dopamine receptor bio- chemistry and pharmacology, they are not derived from the corpus striatum and, therefore, may or may not be relevant for assessing the regulation of receptor effector systems in this brain region. In this regard, a series of recent studies has demonstrated the importance of cell lineage in the use of cell lines as models from specific brain regions. First, the mesencephalic dopaminergic cell line MN9D is much more sensitive than PC1 2 cells to the cytotoxic effects of the dopaminergic neurotoxin $\mathrm{MPP}^{+}$, although both cell lines contain dopamine and accumulate similar levels of $\mathrm{MPP}^{+}$(Choi et al., 1991). Second, in a comparative study of $\mathrm{D}_{2}$-like receptor pharmacology and function, transfected $D_{4}$ receptors have been shown to be linked to the modulation of adenylate cyclase activity in the hybrid MN9D cells, but not in the fibroblast cell line CCL1.3 (Tang et al., 1994). Third, the MN9D cells, in contrast to $\mathrm{PC} 12$ cells, have been shown in reaggregate cultures with primary cells to be capable of responding in a differential fashion to dopaminergic target and nontarget cells (Choi et al., 1992). The MN9D cell line shows a marked reduction in its dopaminergic phenotype when coaggregated with nontarget cells such as optic tectum or thalamus. The specificity of these effects underscores both the potential utility of mesencephalic and corpus striatal cell lines as well as the importance of the specific cellular milieu in providing an appropriate environment for facilitating the expression of brain region-specific properties. The corpus striatal monoclonal hybrid cell lines described in this report recapitulate the biochemistry of primary corpus striatum neurons and their regionspecific lineage and should provide appropriate models for a variety of studies on the neurochemistry of striatal neurons and the role of cell-cell interactions in the regulation of striatal function.

\section{References}

Andersen PH, Gingrich JA, Bates MD, Dearry A, Falardeau P, Senogles SE, Caron MG (1990) Dopamine receptor subtypes: beyond the $D_{1}$ ' $\mathrm{D}_{2}$ classification. Trends Pharmacol Sci 11:231-236.

Balmforth AJ, Ball SG, Freshney RI, Graham DI, McNamee HB, Vaughan PFT (1986) D-1 dopaminergic and beta-adrenergic stimulation of adenylate cyclase in a clone derived from the human astrocytoma cell line G-CCM. J Neurochem 47:715-719.

Balmforth AJ, Yasunari K, Vaughan PFT, Ball SG (1988) Characterization of dopamine and beta-adrenergic receptors linked to cAMP formation in intact cells of the clone D384 derived from human astrocytoma. J Neurochem 51:1510-1515.

Bannon MJ, Roth RH (1983) Pharmacology of mesocortical dopamine neurons. Pharmacol Rev 35:53-68.

Battaglia G, Norman AB, Hess EJ, Creese I (1986) Forskolin potentiates the stimulation of rat striatal adenylate cyclase mediated by D-I dopamine receptors, guanine nucleotides and sodium thuoride. J Neurochem 46:1180-1185.

Bernard V, Normand E, Bloch B (1992) Phenotypical characterization of rat striatal neurons expressing muscarinic receptor genes. J Neurosci 12:3591-3600.

Bertorello AM, Hopfield J, Aperia A, Greengard P (1990) Inhibition by dopamine of $\left(\mathrm{Na}^{+}+\mathrm{K}^{+}\right)$ATPase activity in neostriatal neurons through $D_{1}$ and $D_{2}$ receptor synergism. Nature 347:386-388.

Blusztajn JK, Venturini A, Jackson DA, Lee HJ, Wainer BH (1992) Acetylcholine synthesis and release is enhanced by dibutyryl cyclic AMP in a neuronal cell line derived from mouse septum. J Neurosci 12:793-799.

Bolam JP, Powell JF, Wu J-Y, Smith AD (1985) Glutamate decarboxylase-immunoreactive structures in the rat neostriatum: a correlated light and electron microscopic study including a combination of Golgi impregnation with immunocytochemistry. J Comp Neurol 237:1-20.

Bruinink A, Lichtensteiger W, Schlumpf M (1983) Pre- and postnatal ontogeny and characterization of dopaminergic $D_{2}$, serotonergic $S_{2}$ 
and spirodecanone binding sites in rat forebrain. J Neurochem 40: 1227-1236.

Carlsson A (1988) The current status of the dopamine hypothesis of schizophrenia. Neuropsychopharmacology 1:179-182.

Cashman NR (1991) Cellular and molecular biology of motor neurons: a hybrid cell strategy. Int Brain Res Org Abstr 13.

Cepko CL (1989) Immortalization of neural cells via retrovirus-mediated oncogene transduction. Annu Rev Neurosci 12:47-65.

Childers SR (1985) A high-performance liquid chromatography assay of brain adenylate cyclase using $\left[{ }^{3} \mathrm{H}\right] \mathrm{ATP}$ as a substrate. Neurochem Res 11:161-171.

Chneiweiss H, Glowinski J, Premont J (1988) Mu and delta opiate receptors coupled negatively to adenylate cyclase on embryonic neurons from the mouse striatum in primary cultures. J Neurosci 8:33763382.

Choi HK, Won LA, Kontur PJ, Hammond DN, Fox AP, Wainer BH, Hoffmann PC, Heller A (1991) Immortalization of embryonic mesencephalic dopaminergic neurons by somatic cell fusion. Brain Res 552:67-76.

Choi HK, Won L, Roback JD, Wainer BH, Heller A (1992) Specific modulation of dopamine expression in neuronal hybrid cells by primary cells from different brain regions. Proc Natl Acad Sci USA 89: 8943-8947.

Coyle JT, Axelrod J (1972) Tyrosine hydroxylase in rat brain: developmental characteristics. J Neurochem 19:1117-1123.

Crawford GD Ir, Le W, Smith RG, Xie W, Stefani E, Appel SH (1992) A novel N18TG2 $\times$ mesencephalon cell hybrid expresses properties that suggest a dopaminergic cell line of substantia nigra origin. $\mathrm{J}$ Neurosci 12:3392-3398.

Dearry A, Gingrich J, Falardeau P, Fremeau RT Jr, Bates MD, Caron MG (1990) Molecular cloning and expression of the gene for a human $D_{1}$ dopamine receptor. Nature 347:72-76.

DiFiglia M, Aronin N (1982) Ultrastructural features of immunoreactive somatostatin neurons in the rat caudate-nucleus. J Neurosci 2:1267-1274.

Ehrlich ME, Kurihara T, Greengard P (1990) Rat DARPP-32: cloning, sequencing, and characterization of the cDNA. J Mol Neurosci 2:110.

Eves EM, Tucker MS, Roback JD, Downen M, Rosner MR, Wainer BH (1992) Immortal rat hippocampal cell lines exhibit neuronal and glial lineages and neurotrophin gene expression. Proc Natl Acad Sci USA 89:4373-4377.

Farfel GM, Kleven MS, Woolverton WL, Seiden LS, Perry BD (1992) Effects of repeated injections of cocaine on catecholamine receptor binding sites, dopamine transporter binding sites and behavior in rhesus monkey. Brain Res 578:235-243.

Fink JS, Weaver DR, Rivkees SA, Peterfreund RA, Pollack AE, Adler EM, Reppert SM (1992) Molecular cloning of the rat A2 adenosine receptor: selective co-expression with D2 dopamine receptors in the rat striatum. Mol Brain Res 14:186-195.

Fonnum $F$ (1975) A rapid radiochemical method for the determination of choline acetyltransferase. J Neurochem 24:407-409.

Foster GA, Schultzberg M, Hokfelt T, Goldstein M, Hemmings HC Jr, Ouimet CC, Walaas SI, Greengard P (1987) Development of a dopamine- and cyclic adenosine $3^{\prime}: 5^{\prime}$-monophosphate-regulated phosphoprotein (DARPP-32) in the prenatal rat central nervous system, and its relationship to the arrival of presumptive dopaminergic innervation. J Neurosci 7:1994-2018.

Fournier K (1981) A general high-efficiency procedure for production of microcell hybrids. Proc Natl Acad Sci USA 78:6349-6353.

Gelbard HA, Teicher MH, Faedda G, Baldessarini R (1989) Postnatal development of dopamine $D_{1}$ and $D_{2}$ receptor sites in rat striatum. Brain Res 49:123-130.

Gerfen CR (1988) Synaptic organization of the striatum. J Electron Microsc Tech 10:265-281.

Gerfen CR (1992) The neostriatal mosaic: multiple levels of compartmental organization in the basal ganglia. Annu Rev Neurosci 15: 285-320.

Gerfen CR, Baimbridge KG, Thibault J (1987) The neostriatal mosaic. III. Biochemical and developmental dissociation of dual nigrostriatal dopaminergic systems. J Neurosci 7:3935-3944

Gerfen CR, Engber TM, Mahan LC, Susel Z, Chase TN, Monsma FJ, Sibley DR (1990) $D_{1}$ and $D_{2}$ dopamine receptor-regulated gene expression of striatonigral and striatopallidal neurons. Science 250:1429 1432.
Gingrich JA, Caron MG (1993) Recent advances in the molecular biology of dopamine receptors. Annu Rev Neurosci 16:299-321.

Grandy DK, Civelli O (1992) G-protein-coupled receptors: the new dopamine receptor subtypes. Curr Opin Neurobiol 2:275-281.

Graybiel AM (1990) Neurotransmitters and neuromodulators in the basal ganglia. Trends Neurosci 13:244-254.

Graybiel AM, Ragsdale CW Jr (1983) Biochemical anatomy of the striatum. In: Chemical neuroanatomy (Emson PC, ed), pp 427-504. New York: Raven.

Greene LA, Tischler AS (1976) Establishment of a noradrenergic clonal cell line of rat pheochromocytoma cells which respond to nerve growth factor. Proc Natl Acad Sci USA 73:2424-2428.

Greene LA, Sahin W, Chalazonitis A, Breakefield X, Minna J, Coon HG, Nirenberg M (1975) Neuronal properties of hybrid neuroblastoma $\times$ sympathetic ganglion cells. Proc Natl Acad Sci USA 72:49234927.

Gruneberg H (1943) The development of some external features on mouse embryos. J Hered 34:89-92.

Gustafson EL, Ehrlich ME, Trivedi P, Greengard P (1992) Developmental regulation of phosphoprotein gene expression in the caudate-putamen of rat: an in situ hybridization study. Neuroscience 51: 65-75.

Hammond DN, Wainer BH, Tonsgard JH, Heller A (1986) Neuronal properties of clonal hybrid cell lines derived from central cholinergic neurons. Science 234:1237-1340.

Hammond DN, Lee HJ, Tonsgard JH, Wainer BH (1990) Development and characterization of clonal cell lines derived from septal cholinergic neurons. Brain Res 512:190-200.

Hemmendinger LM, Garber B, Hoffmann PC, Heller A (1981) Target neuron-specific process formation by embryonic mesencephalic neurons in vitro. Proc Natl Acad Sci USA 78:1264-1268.

Hemmings HC Jr, Greengard P (1986) DARPP-32, a dopamine- and adenosine $3^{\prime}: 5^{\prime}$-monophosphate-regulated phosphoprotein: regional, tissue, and phylogenetic distribution. J Neurosci 6:1469-1481.

Hornykiewicz $O$ (1973) Dopamine in the basal ganglia. Its role and therapeutic implications. Br Med Bull 29:172-178.

Hornykiewicz O (1979) Dopamine in Parkinson's disease and other neurological disturbances. In: The neurobiology of dopamine (Horn AS, Korf J, Westerink BHC, eds), pp 633-654. London: Academic.

Ivins KJ, Luedtke RR, Artymyshyn RP, Molinoff PB (1991) Regulation of dopamine $\mathrm{D}_{2}$ receptors in a novel cell line (SUP1). Mol Pharmacol 39:531-539.

Kebabian JW, Calne DB (1979) Multiple receptors for dopamine. Nature 227:93-96.

Killary AM, Fournier RE (1984) A genetic analysis of extinction: transdominant loci regulate expression of liver-specific traits in hepatoma hybrid cells. Cell 38:523-534.

Kita H, Kitai ST (1988) Glutamate decarboxylase immunoreactive neurons in rat neostriatum: their morphological types and populations. Brain Res 447:346-352.

Kontur PJ, Hoffmann PC, Heller A (1987) Neurotoxic effects of methamphetamine assessed in three-dimensional reaggregate tissue cultures. Dev Brain Res 31:7-14.

Lasley SM, Greenland RD, Michaelson IA (1984) Determination of gamma-aminobutyric acid and glutamic acids in rat brain by liquid chromatography with electrochemical detection. Life Sci 35:19211930

Lee HJ, Hammond DN, Large TH, Wainer BH (1990a) Immortalized young adult neurons from the septal region: generation and characterization. Dev Brain Res 52:219-228.

Lee HJ, Hammond DN, Large TH, Roback JD, Sim JA, Brown DA, Otten UH, Wainer BH (1990b) Neuronal properties and trophic activities of immortalized hippocampal cells from embryonic and young adult mice. J Neurosci 10:1779-1787.

Le Moine C, Norman E, Guitenny AF, Fouque B, Teoule B, Bloch B (1990) Dopamine receptor gene expression by enkephalin neurons in rat forebrain. Proc Natl Acad Sci USA 87:230-234.

Lendahl U, McKay RDG (1990) The use of cell lines in neurobiology. Trends Neurosci 13:132-136.

Lester J, Fink S, Aronin N, DiFiglia M (1993) Colocalization of $D_{1}$ and $D$, dopamine receptor mRNAs in striatal neurons. Brain Res 621:106-110.

Lovenberg TW, Roth RH, Nichols DE, Mailman RB (1991) D, dopamine receptors of NS20Y neuroblastoma cells are functionally similar to rat striatal $D_{1}$ receptors. J Neurochem 57:1563-1569. 
Mack KJ, O'Malley KL, Todd RD (1991) Differential expression of dopaminergic $\mathrm{D}_{2}$ receptor messenger RNAs during development. Dev Brain Res 59:249-251.

Mailman RB, Schulz DW, Kilts CD, Lewis MH, Rollema H, Wyrick S (1986) The multiplicity of the $D_{1}$ dopamine receptor. Adv Exp Med Biol 204:53-72.

McGeer EG, Fibiger HC, Wickson V (1971) Differential development of caudate enzymes in the neonatal rat. Brain Res 32:433-440.

Mevel-Ninio M, Weiss MC (1981) Immunofluorescence analysis of the time-course of extinction, reexpression and activation of albumin production in rat hepatoma-mouse fibroblast heterokaryons and hybrids. J Cell Biol 90:339-350.

Minna JD, Yavelow J, Coon HG (1975) Expression of phenotypes in hybrid somatic cells derived from the nervous system. Genetics 79: 373-383.

Monsma FJ Jr, Brassard DL, Sibley DR (1989) Identification and characterization of $D_{1}$ and $D_{2}$ dopamine receptors in cultured neuroblastoma and retinoblastoma clonal cell lines. Brain Res 492:314 324.

Monsma FJ Jr, Mahan LC, McVittie LD, Gerfen CR, Sibley DR (1990a) Molecular cloning and expression of a $D_{1}$ dopamine receptor linked to adenylate cyclase activation. Proc Natl Acad Sci USA 87:67236727.

Monsma FJ Jr, Barton A, Sibley DR (1990b) Expression of functional $\mathrm{D}_{2}$ dopamine receptors following differentiation of Y-79 human retinoblastoma cells. J Neurochem 54:1200-1207.

Moscona AA (1961) Rotation-mediated histogenetic aggregation of dissociated cells. A quantifiable approach to cell interactions in vitro. Exp Cell Res 22:455-475.

Murrin LC, Zeng W (1986) Postnatal ontogeny of dopamine $\mathrm{D}_{2}$ receptors in rat striatum. Biochem Pharmacol 35:1159-1162.

Murrin LC, Zeng W (1990) Ontogeny of dopamine $D_{1}$ receptors in rat forebrain: a quantitative autoradiographic study. Dev Brain Res 57:7-13.

O'Malley KL, Mack KJ, Gandelman KY, Todd RD (1990) Organization and expression of the rat $D_{2 a}$ receptor gene: identification of alternative transcripts and a variant donor splice site. Biochemistry 29:1367-1371.

O'Malley KL, Harmon S, Tang L, Todd RD (1992) The rat dopamine $\mathrm{D}_{4}$ receptor: sequence, gene structure and demonstration of expression in the cardiovascular system. New Biol 4:1-9.

Ouimet CC, Greengard P (1990) Distribution of DARPP-32 in the basal ganglia: an electron microscopic study. J Neurocytol 19:39-52.

Porcher W, Heller A (1972) Regional development of catacholamine biosynthesis in the rat brain. J Neurochem 19:1917-1930.

Potter PE, Meek JL, Neff NH (1983) Acetylcholine and choline in neuronal tissue measured by HPLC with electrochemical detection. J Neurochem 41:188-194.

Prasad KN, Sinha PK (1976) Effect of sodium butyrate on mammalian cells in culture: a review. In Vitro 13:125-132.

Puck TT, Marcus PI, Cieciura SJ (1956) Clonal growth of mammalian cells in vitro. J Exp Med 103:273-284.

Rao PA, Molinoff PB, Joyce JN (1991) Ontogeny of dopamine D, and $D_{2}$ receptor subtypes in rat basal ganglia: a quantitative autoradiographic study. Dev Brain Res 60:161-177.

Ronnett GV, Hester LD, Nye JS, Connors K, Snyder SH (1990) Human cortical neuronal cell line: establishment from a patient with unilateral megalencephaly. Science 248:603-605.

Schalling M, Djurfeldt M, Hokfelt T, Ehrlich M, Kurihara T, Greengard P (1990) Distribution and cellular localization of DARPP-32 mRNA in rat brain. Mol Brain Res 7:139-149.

Seeman P (1987) Dopamine receptors and the dopamine hypothesis of schizophrenia. Synapse 1:133-138.

Seeman P, Niznik HB, Guan H-C, Booth G, Ulpian C (1989) Link between $\mathrm{D} 1$ and $\mathrm{D} 2$ dopamine receptors is reduced in schizophrenia and Huntington diseased brain. Proc Natl Acad Sci USA 86:1015610160.

Seeman P, Guan H-C, Van Tol HHM (1993) Dopamine $D_{4}$ receptors elevated in schizophrenia. Nature 365:441-445.

Sibley DR, Monsma FJ Jr (1992) Molecular biology of dopamine receptors. Trends Pharmacol Sci 13:61-69.

Sidhu A, Fishman PH (1990) Identification and characterization of functional $D_{1}$ dopamine receptors in a human neuroblastoma cell line. Biochem Biophys Res Commun 166:574-579.

Sidhu A, Kebabian JW (1985) An iodinated ligand identifying the D-1 dopamine receptor. Eur J Pharmacol 113:437-440.

Sokoloff P, Giros B, Matres M, Bouthenet M, Schwartz J (1990) Molecular cloning and characterization of a novel dopamine receptor $\left(D_{3}\right)$ as a target for neuroleptics. Nature 347:146-151.

Steffey ME, Snyder GL, Barrett RW, Fink JS, Ackerman M, Adams P, Bhatt R, Gomez E, MacKenzie RG (1991) Dopamine $D_{1}$ receptor stimulation of cyclic AMP accumulation in COS-1 cells. Eur J Pharmacol 207:311-317.

Sternberger LA (1979) The unlabeled antibody peroxidase-antiperoxidase (PAP) method. In: Immunocytochemistry, pp 104-169. New York: Wiley.

Stoof JC, Drukarch B, DeBoer P, Westerink BHC, Groenewegen HJ (1992) Regulation of the activity of striatal cholinergic neurons by dopamine. Neuroscience 47:755-770.

Surmeier DJ, Eberwine J, Wilson CJ, Cao Y, Stefani A, Kitai ST (1992) Dopamine receptor subtypes colocalize in rat striatonigral neurons. Proc Natl Acad Sci USA 89:10178-10182.

Surmeier DJ, Reiner A, Levine M, Ariano MA (1993) Are neostriatal dopamine receptors co-localized? Trends Neurosci 16:299-305.

Tang L, Todd RD, Heller A, O'Malley KL (1994) Pharmacological and functional characterization of $D_{2}, D_{3}$ and $D_{4}$ dopamine receptors in fibroblast and dopaminergic cell lines. J Pharmacol Exp Ther 268 : 495-502.

Tiberi M, Jarvie KR, Silvia C, Falardeau P, Gingrich JA, Godinot N, Bertrand L, Yang-Feng TL, Freneau RT, Caron MG (1991) Cloning, molecular characterization, and chromosomal assignment of a gene encoding a second $D_{1}$ dopamine receptor subtype: differential expression pattern in rat brain compared with the DIA receptor. Proc Natl Acad Sci USA 88:9491-9495.

Trojanowski JQ, Obrocka MA, Lee MY (1983) A comparison of eight different chromogen protocols for the demonstration of immunoreactive neurofilaments or glial filaments in rat cerebellum using the peroxidase-antiperoxidase method and monoclonal antibodies. J Histochem Cytochem 31:12:17-1223.

Vadasz C, Laszlovsky I, DeSimone PA, Fleischer A (1992) Genctic aspects of dopamine receptor binding in the mouse and rat brain: an overview. J Neurochem 59:793-808

Wainer BH, Heller A (1992) Neuronal cell lines: generation, characterization and utility. In: Neuronal cell lines: essential tools in neurobiology (Wood JN, ed), pp 1-26. New York: Oxford UP.

Wainwright MS, Wang W-Y, Won LA, Heller A (1993) Immortalization of a cholinergic cell line derived from murine corpus striatum. Soc Neurosci Abstr 19:915.

Zeng W, Hyttel J, Murrin LC (1988) Ontogeny of dopamine $D_{1}$ receptors in rat striatum. $J$ Neurochem 50:862-867.

Zhou QY, Grandy DK, Thambi I, Kushner JA, Van-Tol HH, Cone R, Pribnow D, Salon J, Bunzow JR, Civelli O (1990) Cloning and expression of human and rat $D_{1}$ dopamine receptors. Nature 347:7680.

Zhou QY, Li C, Civelli O (1992) Characterization of gene organization and promoter region of the rat dopamine $D_{1}$ receptor gene. J Neurochem 59:1875-1883.

Zivin JA, Waud DR (1982) How to analyze binding, enzyme and uptake data: the simplest case, a single phase. Life Sci 30:1407-1425. 